$\underline{\xi}=-m$

\title{
Hepatorenal protective effect of ocimum sanctum in chickens toxicated by gentamicin
}

\author{
Hadeer A. M. Abdul Ghaffar ${ }^{1 *}$, Ashraf A. A.Elkomy², Enas A.H. Farag ${ }^{3}$ \\ ${ }^{1}$ Veterinary medicine directorate- Shebien Elkom \\ ${ }^{2}$ Head of pharmacology department faculty of veterinary medicine Benha university \\ ${ }^{3}$ Chief researcher of pharmacology-Animal health research institute \\ *Corresponding author E-mail:drhadeermohamady@gmail.com
}

\begin{abstract}
Background: ocimum sanctum (Tulsi) "Queen of herbs" is considered as sacred and medicinal plant in a lot of countries around the world especially India. Therefore this study was carried out to investigate the heptorenal protective effect of ocimum sanctum aqueous extract against gentamicin induced hepatorenal toxicity in chickens.

Materials and Methods: A total 100, one-day old unsexed broiler chicks of a commercial breed (Cobb breed) were used in this study, the chickens were subjected to different treatments blood and tissue samples were collected at $5^{\text {th }}$ week of age post administration, biochemical and histopathological examinations were utilized to investigate protective effect of ocimum sanctum aqueous extract on liver and kidney.

Results: gentamicin recorded significant $(\mathrm{P}<0.05)$ increase in serum level of aspartate aminotransferase (AST), alanine aminotransferase (ALT), uric acid and creatinine levels when compared with control group, the administration of ocimum sanctum aqueous extract with gentamicin ameliorate their toxic effect, the group treated with ocimum sanctum aqueous extract only similar to control, while gentamicin induce significant $(\mathrm{P}<0.05)$ decrease in serum albumin, total protein and globulin levels when compared with control group, ocimum sanctum aqueous extract with gentamicin restore their toxic effect. The group treated with ocimum sanctum aqueous extract only as control. Gentamicin induce histopathological alterations in liver and kidney tissues by comparison with control group and ocimum sanctum aqueous extract treated group as control, while the administration of ocimum sanctum aqueous extract with gentamicin showing improvement in histopathological lesion compared with toxic effect induced by gentamicin.

Conclusions: The hepatotoxicity and nephrotoxicity induced by gentamicin were ameliorated by aqueous extract of ocimum sanctum especially at dose of $2 \mathrm{ml} /$ liter in drinking water for 12 days.
\end{abstract}

Keywords: Hepatotoxicity; Nephrotoxicity; Ocimum sanctum; Chickens; Gentamicin.

\section{Introduction}

Aminoglycosides remain one of the important antibiotics in medical practice as amikacin, gentamicin, isepamicin, kanamycin, neomycin, netilmicin, paromomycin, sisomicin, streptomycin, dihydrostreptomycin, and tobramycin (Aronson 2016). Aminoglycosides are chemically similar, have many features in common especially in their mechanism of antibacterial action, a broad antibacterial spectrum, partial or complete cross-resistance, bactericidal action in a slightly alkaline environment, poor absorption from the gastrointestinal tract, elimination by glomerular filtration, nephrotoxicity, ototoxicity, a potential to cause neuromuscular blockade, and partial or complete cross allergy (Aronson 2016). Gentamicin, a member of aminoglycosides, is mostly used in treatment of several bacterial diseases in both human and animals (Kang et al., 2013) and various diseases caused by many gram-negative and some grampositive bacteria in poultry farms (Haritova et al., 2004). However, gentamicin is nephrotoxic (Islam et al., 2011) owing to its accumulation in renal tubular epithelial cells (Laureat et al., 1983) causing kidney enlargement and alterations similar to other causes of renal failure (Schmidt et al., 2003). Hemorrhages and acute tubular necrosis in kidney, hemorrhages, cellular infiltration and fatty degeneration of hepatocytes in liver are different lesions that induced by the use of gentamycin (Islam et al., 2011). So, it is important to seek for non-toxic and effective medicinal plants with anti-oxidative activity (Lobo et al., 2010). Herbal preparations were worldwide used as nutritional supplements as they considered to be "natural" and consequently are free of adverse reactions (Strader et al., 2002). Their ingredients were main source of natural antioxidants which might be useful in preventing damage induced by oxidative stress (Masood et al., 2008).Co administration of various medicinal plants along with nephrotoxic substances possessing nephroprotective effect may decrease their toxicity (Shin et al., 2014). Tulsi is aplant belongs to the family Labiatae, characterized by square stem and specific aroma. Botanical name of Tulsi is Ocimum sanctum Linn (Anonymous 1991) and (Verma 2016). Tulsi plant has hepatoprotective, immunomodulatory, analgesic, antipyretic properties and is used as a diaphoretic in malarial fever.Tulsi is ever applicable to a wide range of conditions ranging from minor illnesses as cold or a cough to different severe conditions. Ocimum sanctum (Tulsi) has been researched on a major scale and has shown a plenty of biological and pharmacological activities benefiting humans since ages (Gupta et al., 2002) and (Prakash and Gupta 2005). 


\section{Material and methods}

\subsection{Gentamicin:}

Gentacure $10 \%$ (Injectable solution: each $1 \mathrm{ml}$ contains GM sulfate $120.5 \mathrm{mg}$ equivalent GM base $100 \mathrm{mg}$ ). It was administrated at dose of 5 o $\mathrm{mg} / \mathrm{Kg}$ for 5 days.

\subsection{Ocimum sanctum:}

Ocimum Sanctum was purchased from local market, Shebien El Kom City, Menoufia Governrate, Egypt. It was given at dose of $2 \mathrm{ml} / \mathrm{liter}$ in drinking water for 12 days.

\subsection{Preparation of Ocimum Sanctum Extract:}

After collection of fresh mature leaves of ocimum sanctum, they were washed and cleaned well. Then were chopped into small pieces by scissors and water was added at 1:10 ratio. The extract was prepared by mixing the leaves with pestle and motor and stored in a refrigerator at $4^{\circ} \mathrm{C}$ to maintain the active ingredients of the extract (Alom et al., 2015).

\subsection{Chickens and experimental design:}

A total 100, one-day old unsexed broiler chicks of a commercial breed (Cobb breed) obtained from El-Watania Poultry Company, Cairo, Egypt. All chicks placed in cleaned and disinfected cages which placed in good ventilated cleaned room and hygienic condition, supplied with balanced commercial ration free from any medications and water was provided adlibitum. At $17^{\text {th }}$ day chicks were divided randomly into 4 groups each one contained 25 birds.

Group (1): served as untreated control group were administered saline only.

Group (2): was given only gentamicin at dose of $50 \mathrm{mg} / \mathrm{Kg} \mathrm{B.W}$. intramuscular twice daily for 5 days from day 24 th till day $28^{\text {th }}$ old chicks.

Group (3): was given only $2 \%$ ocimum sanctum aqueous leave extract for 12 days $2 \mathrm{ml} /$ liter in drinking water from day $17^{\text {th }}$ till day 28thold chicks.

Group (4): was given $2 \%$ ocimum sanctum aqueous leave extract for 12 days from day $17^{\text {th }}$ till day $28^{\text {th }}$ old chicks $2 \mathrm{ml} /$ liter in drinking water + gentamicin at dose of $50 \mathrm{mg} / \mathrm{Kg} \mathrm{B.W}$. intramuscular twice daily for 5 days from day $24^{\text {th }}$ till day $28^{\text {th }}$ old chicks. All birds were scarified at $5^{\text {th }}$ week of age.

\subsection{Sampling:}

Blood samples were collected from the wing veins of birds before scarified at $5^{\text {th }}$ week in all groups for biochemical analysis. The blood samples were collected without anticoagulant and centrifuged at (3,000 $\times \mathrm{g} 10 \mathrm{~min})$ for separation of clear serum for biochemical analysis. These serum samples were used for biochemical analysis to determine Aspartate aminotransferase (AST) and Alanine aminotransferase (ALT), total protein (TP), albumin, globulin, uric acid and creatinine (Kaneko et al., 1997 and Arafat et al., 2017).

\subsection{Serum biochemical analysis:}

Aspartate aminotransferase (AST) and serum alanin aminotranseferase (ALT) were colorimetrically determined by method described by Murray and kaplan (1984) using kits from Diamond diagnostic (Egypt). Total protein concentration in serum was determined calorimetrically by the method described by Koller (1984) using kits from Diamond Diagnostic Company (Egypt). Albumin concentration in serum was determined calorimetrically by the method described by Doumas et al., (1971) using kits from Diamond Diagnostic Company (Egypt). According to Rabab et al., (2013) total globulins were calculated as follow: Globulins = Total protein- Albumin. Determination of serum uric acid was carried out by spectrophotometer, using specific kits according White et al., (1970). Creatinine concentration in serum was determined calorimetrically by the method described by Murray (1984) using kits from Diamond Diagnostic Company (Egypt).

\subsection{Histopathology study:}

Autopsy sample were taken from the liver and kidney of chickens several groups and fixed in $10 \%$ formalin saline for 7 days, after completion of fixation, the samples were dehydrated in a series of alcohols, cleared in toluene and then embedded in paraplast (Sherweed Medical Co, USA). Blocks were cut at 5-7 $\mu \mathrm{m}$. Sections were de-waxed, re-hydrated in a series of alcohols, stained in Harris hematoxylin (Cole Par-mer, USA) and counterstained in 1\% aqueous eosin (Sigma, USA). Sections were then mounted in DePeX (GURR, BDH, UK) and ex-amined under a light microscope. Representative slides were photographed under an Olympus Vanox photomicroscope (Olympus, USA) (Al-Naqeeb et al., 2003).

\subsection{Statistical analysis:}

Statistical analysis was conducted with the Statistical Package for Social Science (SPSS 16 Inc. Released, 2009) to determine if variables differed among groups, Comparison among means was conducted by one-way ANOVA and subsequent Ducann's multiple range test, Probability values of less than $5 \%(\mathrm{p} \leq 0.05)$ were considered significant.

\section{Results:}


Gentamicin induced a significant $(\mathrm{P}<0.05)$ increase in the level of serum AST, ALT, uric acid and creatinine levels compared to the control group and $2 \%$ ocimum sanctum treated group as control and administration of $2 \%$ ocimum sanctum extract restore the toxic effect of gentamicin (Table1.)

Table 1: The Effect of Gentamicin And/Or Ocimum Sanctum on Serum AST, ALT, Uric Acid And Creatinine In Chickens (N=10)

\begin{tabular}{|c|c|c|c|c|}
\hline Groups/Parameter & AST (U/L) & ALT (U/L) & uric acid $(\mathrm{g} / \mathrm{dl})$ & creatinine $(\mathrm{U} / \mathrm{L})$ \\
\hline $\begin{array}{l}\mathrm{G}(1) \\
\text { control }\end{array}$ & $51.69 \pm 0.478^{c}$ & $25.6367 \pm 0.409^{c}$ & $9.563 \pm 0.3875^{c}$ & $0.32 \pm 0.0057^{\mathrm{c}}$ \\
\hline$G(2)$ & $52.57 \pm 0.5166^{c}$ & $25.4667 \pm 0.519^{c}$ & $9.903 \pm 0.3875^{c}$ & $0.33 \pm 0.0057^{\mathrm{c}}$ \\
\hline Ocimum Sanctum & & & & \\
\hline $\begin{array}{c}\mathrm{G}(3) \\
\text { Gentamicin }\end{array}$ & $71.693 \pm 0.478^{a}$ & $34.4667 \pm 0.519^{a}$ & $17.5 \pm 0.3875^{\mathrm{a}}$ & $1.26 \pm 0.0057^{\mathrm{a}}$ \\
\hline $\begin{array}{c}\text { G (4) } \\
\text { Ocimum Sanctum } \\
\text { and Gentamicin }\end{array}$ & $62.69 \pm 0.478^{b}$ & $29.5367 \pm 0.4297^{b}$ & $12.29 \pm 0.3875^{b}$ & $0.58 \pm 0.0057^{b}$ \\
\hline
\end{tabular}

Values are presented as means \pm SE. Means within a column with different letter superscripts are significantly different. G (group), AST (aspartate aminotransferase), ALT (alanine aminotransferase)

The concentrations of total protein, albumin and globulin levels were significantly $(\mathrm{P}<0.05)$ decreased in gentamicin group compared to control group and $2 \%$ ocimum sanctum treated group as control, administration of $2 \%$ ocimum sanctum aqueous leave extract for 12 days $2 \mathrm{ml} /$ liter in drinking water with gentamicin significantly improve level of albumin, total protein and globulin. (Table 2)

Table 2: The Effect of Gentamicin And/Or Ocimum Sanctum on Serum total protein, albumin and globulin levels In Chickens (N=10)

\begin{tabular}{|c|c|c|c|}
\hline Groups/Parameter & total protein $(\mathrm{g} / \mathrm{dl})$ & albumin $(\mathrm{g} / \mathrm{dl})$ & globulin (g/dl) \\
\hline $\begin{array}{l}\mathrm{G}(1) \\
\text { control }\end{array}$ & $4.32 \pm 0.4738^{a}$ & $2.60 \pm 0.0577^{\mathrm{a}}$ & $1.72 \pm 0.41617^{a}$ \\
\hline G (2) & $4.253 \pm 0.502^{\mathrm{a}}$ & $2.70 \pm 0.0577^{\mathrm{a}}$ & $1.55 \pm 0.533^{\mathrm{a}}$ \\
\hline $\begin{array}{c}\text { Ocimum Sanctum } \\
\text { G (3) }\end{array}$ & $2.87 \pm 0.4738^{b}$ & $1.51 \pm 0.0577^{\mathrm{c}}$ & $1.36 \pm 0.416^{b}$ \\
\hline $\begin{array}{c}\text { Gentamicin } \\
\mathrm{G}(4)\end{array}$ & $4.0467 \pm 0.4359^{a}$ & $2.10 \pm 0.0577^{\mathrm{a}}$ & $1.946 \pm 0.3808^{a}$ \\
\hline $\begin{array}{l}\text { Ocimum Sanctum } \\
\text { and Gentamicin }\end{array}$ & & & \\
\hline
\end{tabular}

Values are presented as means \pm SE. Means within a column with different letter superscripts are significantly different. G (group)

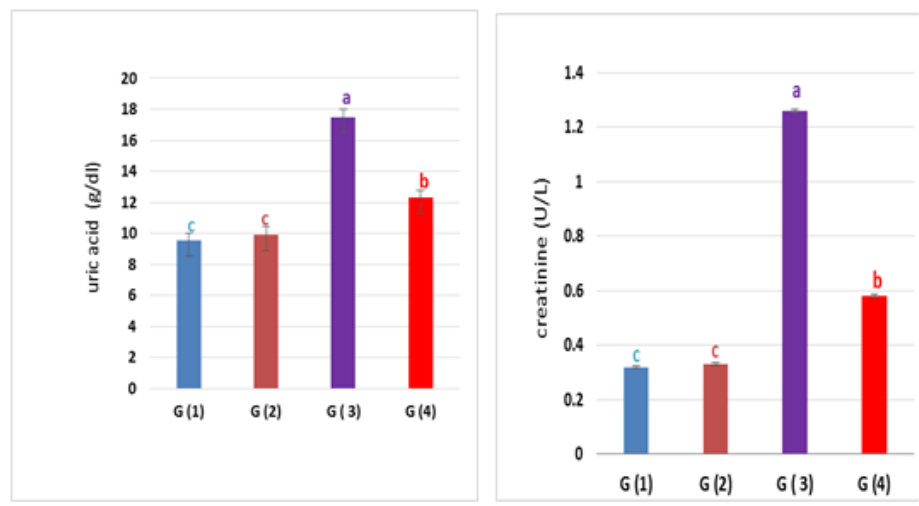

Fig. 1: Gentamicin induced a significant $(\mathrm{P}<0.05)$ increase in the level of serum uric acid and creatinine levels compared to the control group and $2 \%$ ocimum sanctum treated group as control and administration of $2 \%$ ocimum sanctum extract ameliorate the toxic effect of gentamicin G1 (control group); G2 (ocimum sanctum treated group); G3 (gentamicin treated group); G4 (ocimum sanctum and gentamicin treated group)

Microscopical examination of different sections taken form specimens of Liver of control group showed no histopathological alteration normal central vein and hepatic parenchyma (Figure 2 Picture A). In chickens group which treated with gentamicin (at dose of $50 \mathrm{mg} / \mathrm{Kg}$ B.W) only, the livers showed congestion of the central veins, portal vessels and sinusoids. The portal areas showed mild to moderate mononuclear inflammatory cells infiltration and marked hyperplasia of bile ducts with newly formed bile ductules (Figure 2 Picture B,C) The hepatic parenchyma showed granular and vacuolar degeneration of the hepatocytes with scattered necrotic cells either with pyknotic nuclei or without any nuclear structure (Figure 2 Picture C). However examination of livers of chickens treated with both ocimum sanc- 
tum and gentamicin, showed fairly good protection of the hepatic parenchymal cells with only congested hepatic vessels (Figure 2 Picture E) and scattered degenerated and necrotic hepatic cells. The chicken group treated with $2 \%$ ocimum sanctum aqueous extract for 12 days $2 \mathrm{ml} /$ liter in drinking water showed normal liver structure similar to control group (Figure 2 Picture F).
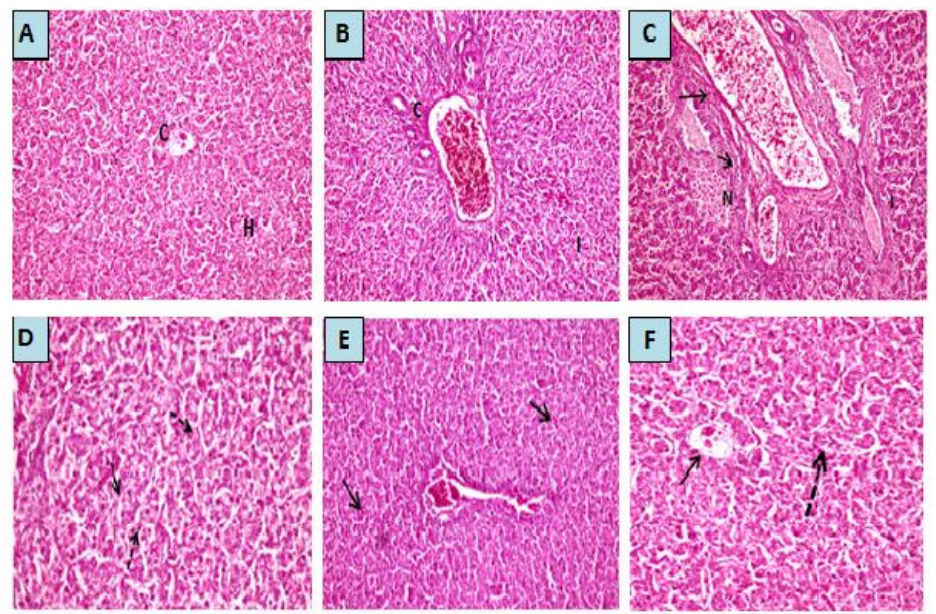

Fig. 2: Histopathological changes of hepatic tissue: Picture [A]: Liver of control chick showing normal central vein(C) and hepatic parenchymal cells (H), (H\&E, X200). Picture [B]: Portal area of liver of chicken treated with gentamicin only showing congestion (C), mild inflammatory cells infiltration (I) and mild hyperplasia of bile duct (H\&E, X200). Picture [C]: Portal area of liver of chickens treated with gentamicin only showing marked hyperplasia of bile duct (arrow), congestion, inflammatory cells infiltration (I) and focal area of hepatocellular necrosis (N). (H\&E, X400). Picture [D]: Liver of chickens treated with gentamicin only showing granular and vacuolar degeneration (dashed arrow) of the hepatocytes with scattered necrotic cells. Notice the congested sinusoids (arrow). (H\&E, X200). Picture [E]: Liver of chickens and treated with ocimum sanctum and gentamicin showing good restoration of the hepatic cell, scattered degenerated and necrotic cells (arrow), (H\&E, X200). Picture [F]: Liver of chick treated with ocimum sanctum only showing normal central vein (arrow) and hepatic parenchymal cells (dashed arrow), (H\&E, X200).

Microscopical examination of different sections taken form specimens of kidney of control group showing normal renal glomeruli and renal tubules (Figure 2 Picture A). The lesions of the kidneys in chickens group which treated with gentamicin only showed congestion of the glomerular capillaries and moderate degree of degeneration and necrosis of the renal tubular epithelium (Figure 2 Picture B).The kidneys showed near to normal appearance of the renal tubular epithelium and renal glomeruli in chickens treated with ocimum sanctum and gentamicin (Figure 2 Picture C). The kidneys of chicken group treated with $2 \%$ ocimum sanctum aqueous extract for 12 days $2 \mathrm{ml} /$ litre in drinking water showed normal kidney structure similar to control group (Figure 2 Picture D).
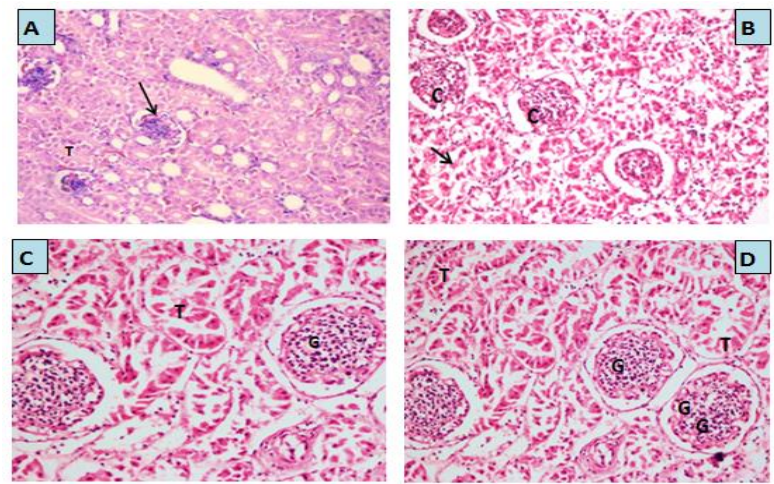

Fig. 3: Histopathological changes of renal tissue: Picture $[\mathrm{A}]$ : Kidney of control group showing normal renal glomeruli (arrow) and renal tubules (T). Picture [B]: Kidney of chicken treated with gentamicin only showing congestion of the glomerular capillaries(C), tubular degeneration, necrosis and desquamation of the renal tubular epithelium (arrow), (H\&E X400). Picture [C]: Kidney of chickens treated with ocimum sanctum and gentamicin showing near to normal appearance of the renal tubular epithelium (T) and renal glomeruli (G). Picture [D]: Kidney of chicken treated with ocimum sanctum only showing normal renal glomeruli $(\mathrm{G})$ and renal tubules $(\mathrm{T})$

Our findings revealed that treatment with $2 \%$ ocimum sanctum aqueous extract for 12 days $2 \mathrm{ml} / \mathrm{liter}$ in drinking water as evidenced by return the levels of AST, ALT, total protein, albumin, globulin, uric acid and creatinine toward normal level and ameliorate hepatorenal toxic effects induced by gentamicin.

\section{Discussion}

The effect of gentamicin at dose of $50 \mathrm{mg} / \mathrm{Kg} \mathrm{B.W.} \mathrm{intramuscular} \mathrm{twice} \mathrm{daily} \mathrm{for} 5$ days on serum ALT and AST showed significant increase which resulted from liver damage and indicated alteration in cell membrane integrity or biliary epithelium Center (2007) and there was significant decrease in total protein and albumin levels due to hepatotoxicity. Hypoproteinemia and Hypoalbuminemia may be due to decrease synthesis of serum proteins associated with severe hepatocellular damage or excessive excretion/loss through destroyed kidneys Tennant and Center (2008).The obtained results in agreement with those obtained by Khan et al., (2008), Saleemi et al., (2009), Arivuchelvan et al., (2012), Javed et al., (2013), El-Zoghby et al., (2013), Abou Elazab and El-habashi ( 2015), Arafat et al., (2017) and Arafat et al., (2018). The group treated with $2 \%$ ocimum sanctum aqueous leave extract for 12 days $2 \mathrm{ml} / /$ liter in drinking water did not 
differ from control group. The obtained result came in agreement with Gupta and Charan (2007) revealed that the effect of ocimum sanctum leaves powder up to $200 \mathrm{mg} / \mathrm{bird}$ for 15 days on serum ALT and AST levels near to normal levels. But when given at dose of (300, 400, 500 and $600 \mathrm{mg} / \mathrm{bird}$ ) for 15 days cause significant decrease in AST level indicating stable hepatic status.Also Arivuchelvan et al., (2012) recorded that effect of $1 \%$ or $2 \%$ ocimum sanctum crud extract with feed on serum total protein and albumin levels similar to control group. In the group that treated with combination of $2 \%$ ocimum sanctum aqueous leave extract plus gentamicin we found that ocimum sanctum modulate the increase in level of serum ALT and AST and the decrease in total protein and albumin levels and return the values around the normal levels confirming hepatoprotective role of ocimum sanctum aqueous leave extract. These result in matched with Bharavi et al., (2011) who recorded that ocimum sanctum opposite the effect of cadmium on serum ALT level and restored it to the normal values. Arivuchelvan et al., (2012) revealed that the combination of $1 \%$ or $2 \%$ ocimum sanctum crud extract with gentamicin at dose of (30 and $50 \mathrm{mg} / \mathrm{kg}$ ) would increase serum total protein and albumin levels around the normal levels confirming hepatoprotective effect of Tulsi. Kumari (2012) recorded that ocimum sanctum leaf at dose of $5 \mathrm{~g} / \mathrm{kg}$ of feed not only ameliorated the increase of serum ALT and AST levels of experimentally infected chickens with E. coli O78 @ 107CFU/0.5 ml at 7 days of age but also improved the decrease in total protein and albumin levels confirming hepatic protection activity of ocimum sanctum. The effect of toxic dose of gentamicin 50mg/Kg B.W. on serum globulin showed significant decrease. These result in matched with Arivuchelvan et al., (2012) and Arafat et al., (2017). Also these result in contrast with El-Zoghby et al., (2013) who recorded significant increase in globulin (IgM and $\mathrm{IgA}$ ) in chicken injected with gentamicin intramuscular at dose of $10 \mathrm{mg} / \mathrm{Kg} \mathrm{B}$.W. The effect of $2 \%$ ocimum sanctum aqueous leave extract for 12 days $2 \mathrm{ml} /$ litre in drinking water on serum globulin showed normal values. This result in matched with Arivuchelvan et al., (2012). The compination of $2 \%$ ocimum sanctum aqueous leave extract with gentamicin ameliorate serum globulin level and return around the normal value. This result in matched with Arivuchelvan et al., (2012) revealed that the combination of $1 \%$ or $2 \%$ ocimum sanctum crud extract with gentamicin at dose of $(30$ and $50 \mathrm{mg} / \mathrm{kg}$ ) would increase serum globulin level near to normal values confirming hepatoprotective and immunomodulatory effect of Tulsi. The results illustrated also significant increase in uric acid and creatinine levels in group that treated with gentamicin at dose of $50 \mathrm{mg} / \mathrm{Kg} \mathrm{B.W}$. The results came in agreement with Khan et al., (2008), Saleemi et al., (2009), Javed et al., (2013), El-Zoghby et al., (2013), Abou Elazab and El-habashi ( 2015), Arafat et al., (2017), Yildirim et al., (2017), Arafat et al., (2018). On the other hand the group treated with $2 \%$ ocimum sanctum aqueous leave extract at dose of $2 \mathrm{ml} / \mathrm{litre}$ in drinking water showed non-significant variation from control group. The results came in agreement with Gupta and Charan (2007) revealed that the effect of ocimum sanctum leaves powder up to $200 \mathrm{mg} / \mathrm{bird}$ for 15 days on serum uric acid and creatinine levels near to normal levels. The group treated with combination of $2 \%$ ocimum sanctum aqueous leave extract plus gentamicin showed values near to normal ones. These results came in matched with Bharavi et al., (2011) who revealed that ocimum sanctum reverse the effect of cadmium on serum creatinine level and restored it to the normal values.

\section{Conclusion}

In the present work, it was concluded that gentamicin at dose of $50 \mathrm{mg} / \mathrm{kg} \mathrm{B.W}$. intramuscular twice daily for 5 days cause elevation in the mean values of serum ALT, AST, uric acid and creatinine as well as decreasing in the mean values of serum total protein, albumin and globulin provide evidence for the hepatorenal toxic effects of the gentamicin. Ocimum sanctum aqueous extract for 12 days at dose of $2 \mathrm{ml} /$ liter in drinking water has ameliorating effects on liver and kidney functions therefore; these effects confirming that ocimum sanctum act as hepatorenal protective agent so it was recommended that chicken should be treated with Ocimum sanctum to protect them from adverse effects induced by antibiotics as gentamicin.

\section{Acknowledgement}

Authors would like to express their deepest gratitude and sincere thanks to Prof. Dr. Ashraf A. A. El-Komy, Professor and head of Phamacology Department, Faculty of Veterinary Medicine, Benha University, for his guidance for liquorice extraction. Dr. Enas A. H. Farag, Chief researcher of pharmaology Animal health research institute Benha branch, for her continual directions and helps.

\section{Funding: no funding sources}

Ethical approval: chickens were treated in accordance with the Guidelines for Animal Experimentation of the Ethics Review Committee of the Faculty of Veterinary Medicine, Benha University, Egypt.

\section{References}

[1] Abou Elazab MF and El-Habashi N (2015), Gentamicin-induced nephrotoxicity in chickens: Modulatory Role Of Moringa Oleifera. Vol. 61, No. 144.Fauci AS, Braunwald E, Kasper DL \& Hauser SL (2008), Principles of Harrison's Internal Medicine, Vol. 9, 17thedn. McGraw-Hill, New York, NY, pp.2275-2304.

[2] Al-Naqeeb MA, Thomson M, Al-Qattan K, Kamel F, Mustafa T and Ali M (2003), Biochemical and histopathological toxicity of an aqueous extract of ginger in female rats. Kuwait journal of science and engineering 30, 35-48.Lee JR, Kim SA, Yoo JW \& Kang YK (2007), The present status of diabetes education and the role recognition as a diabetes educator of nurses in korea. Diabetes Research and Clinical Practice 77, $199-204$.

[3] Alom F, Mostofa M, Alam M, Sorwar M, Uddin J and Rahman M (2015), Effects of indigenous medicinal plant Tulsi (Ocimum sanctum) leaves extract as a growth promoter in broiler. Research in Agriculture Livestock and Fisheries, vol. 2, issu(1),pp. 97-102.

[4] Anonymous (1991), Wealth of India. Publication and Information Directorate, CSIR, New Delhi. Vol. (7); p. 79-89.

[5] Arafat N, EL-Shafei R, Awadin W, Farag V and Saleh R (2017), Consequencs of hepatorenal toxicity induced by gentamicin in chickens. Vol. 63 No. 154, pp 1-12.

[6] Arafat N, AwadinWF, El-Shafei RA, Farag VME and Saleh RM (2018), Protective Role of Moringa oleifera Leaves Extract Against Gentamicininduced Nephro- and Hepato- Toxicity in Chickens. Vol. 58 (1): 173-185.

[7] Arivuchelvan A, Murugesan S, Mekala P and Yogeswari R (2012), Immunomodulatory Effect of Ocimum sanctum in Broilers Treated with High Doses of Gentamicin.

[8] Aronson JK (2016), Meyler's Side Effects of Drugs (Sixteenth Edition) The International Encyclopedia of Adverse Drug Reactions and Interaction, Pages 216-236. 
[9] Bharavi K, Gopala Reddy A, Rao GS, Ravi Kumar P, D Srinivas Kumar, P Prabhu Prasadini (2011), Prevention of cadmium bioaccumulation by herbal adaptogens. Indian J Pharmacol. Vol.43(1): pp. 45-49.

[10] Center SA (2007), Interpretation of liver enzymes. Vet. Clin. North Am. Small Anim. Pract. 37(2), $297-333$.

[11] Doumas BT, Watson WA and Biggs HG (1971), Albumin standards and the measurement of serum albumin with bromcresol green. Clin Chim Acta. Vol. 31: pp. 87-96.

[12] EL-Zoghby R, Abo-Kora S and Amin A (2013), Pathological And Clinicopathological Studies on The Effect of Gentamicin And I or Cefotaxime on Chicken. Vol. 26, No.2, pp. 89- 105 .

[13] Gupta G and Charan S (2007), Exploring the potentials of Ocimum sanctum ( Shyama tulsi) as a feed supplement for its growth promoter activity in broiler chickens. Vol. (42), issue (2).pp. 140-143.

[14] Gupta SK, Prakash J and Srivastava S (2002), Validation of traditional claim of Tulsi, Ocimum sanctum Linn. as a medicinal plant. Indian J Exp Biol. Vol. 40 (7): pp. 765-773.

[15] Haritova AM, Djeneva HA, Lashev LD, Sotirova PG, Gurov BI and Dyankov VN (2004), Pharmacokinetics of gentamicin and apramycin in tukeys roosters and hens in the context of pharmacokinetic-pharmacodynamic relationships. J. Vet. Pharm. Ther. 27(5), 381-384.

[16] Islam NU, Khan MZ, Saleemi MK, Khan A, Bhatti SA, Yousaf M and Hassan ZU (2011), Clinicopathological studies on gentamicin toxicity in White Leghorn commercial layers. Pak. Vet. J. 31(4), 305-308.

[17] Javed U, Khan MZ, Saleemi MK, Ahrar Khan, Javed I and Rafique S (2013), Toxico-pathological Effects of Parenteral Administration of Gentamicin in Growing Broilers. Vol 15: issu (3), pp 529-534.

[18] Kang C, Lee H, Hah DY, Heo JH, Kim CH, Kim E and Kim JS (2013), Protective effects of Houttuynia cordata Thunb. on gentamicin- induced oxidative stress and nephrotoxicity in rats. Toxicol. Res. 29(1), 61-67.

[19] Khan I, Khan M, Kashif M and Javed I (2008), Pathological and Biochemical Effects of Intramuscular Gentamicin Administration in Chickens. Vol. 32(5): pp.345-351.

[20] Koller A (1984), Total serum protein. Clin. Chem. The C.V. Mosby Co. St Louis. Toronto. Princeton. Pp. 1316-1324.

[21] Kumari M (2012), Clinico-pathological and Immunological studies in Escherichia coli infected broiler chicks fed on Ocimum sanctum leaf supplemented feed.

[22] Laureat G, Maldague P, Carlier MB and Tulkens PM (1983), Increased renal DNA synthesis in vivo after administration of low doses gentamicin to rats. Antimicrob. Agent Chemother. 24(4), pp. 586-593.

[23] Lobo V, Patil A, Phatak A and handra N (2010), Free radicals, antioxidants and functional foods: impact on human health. Pharmacog. Rev. 4(1), 18-26.

[24] Masood A, Nadeem A, Mustafa SJ and O’Donnell JM (2008), Reversal of oxidative stress-induced anxiety by inhibition of phosphodiesterase-2 in mice. J. Pharmacol. Exp. Ther. 326(2), 369-379.

[25] Murray R and Kaplan A (1984), Aspartate aminotransferase. Clin. Chem. The C.V. Mosby Co. St Louis. Toronto. Princeton. Pp. $1112-1116$.

[26] Murray R.L. (1984), Creatinine. Clin. Chem. The C.V. Mosby Co. St Louis. Toronto. Princeton. Pp.1261-1266 and 418.

[27] Prakash P and Gupta N (2005), Therapeutic uses of Ocimum sanctum Linn (Tulsi) with a note on eugenol and its pharmacological actions: a short review. Indian J Physiol Pharmacol. Vol. (49): pp.125-131.

[28] Saleemi MK, Khan MZ, Javed I and Khan A (2009), Pathological effects of gentamicin administered intramuscularly to day-old broiler chicks. Volume 61, Issue 5, Pages 425-432.

[29] Schmidt RE, Reavill DR and Phalen DN (2003), Urinary system. In: Pathology of pet and aviary birds. Ames (IA): Iowa State Press, 95-107.

[30] Shin HS, Yu M, Kim M, Choi HS and Kang DH (2014), Renoprotective effect of red ginseng in gentamicininduced acute kidney injury. Lab. Invest. 94(10), 1147- 1160 .

[31] SPSS Inc. Released (2009), PASW Statistics for Windows, Version 18.0. Chicago: SPSS Inc.

[32] Strader DB, Bacon BR, Lindsay KL, La Brecque DR, Morgan T, Wright EC, Allen J, Khokar MF, Hoofnagle JH and Seeff LB (2002), Use of complementary and alternative medicine in patients with liver disease. Am. J. Gastroenterol. 97, 2391-2397

[33] Tennant BC and Center SA (2008), Hepatic function. In Kaneko J.J., Harvey J.W., BrussM.L. (Eds.), Clinical Biochemistry of Domestic Animals. Sixth Edition. Academic Press; New York; p.379-412.

[34] Verma S (2016), Chemical constituents and pharmacological action of Ocimum sanctum (Indian holy basil-Tulsi). 5(5): 205-207.

[35] White BA, Erickson MM and Stevens SG (1970), Colorimetric determination of uric acid. Chemistry for medical technologists 3rd ed C. V. Mosby Company, saint Louis, U .S.A.P(662)

[36] Yildirim BA, Tunc MA, Yildirim S, Yildirim F, Kordali S, Ertekin A and Aktas Senocak E (2017), The effect of Vitis vinifera L. cv. Merlot seed extract on gentamicin-induced nephrotoxicity in broilers. Vol. 81, pp. 1-12 